Reviu Akuntansi dan Bisnis Indonesia, Vol. 1 No. 1, Hlm: 36-46, Juli 2017

Website: http://journal.umy.ac.id/index.php/rab

\title{
Pengaruh Struktur Kepemilikan dan Mekanisme Corporate Governance terhadap Tingkat Kepatuhan Mandatory Disclosure Konvergensi IFRS : Studi Empiris pada Perusahaan Manufaktur yang Terdaftar di BEI 2012- 2015
}

\author{
Farda Fauzia; Evi Rahmawati \\ Program Studi Akuntansi Universitas Muhammadiyah Yogyakarta
}

I N F O A R T I K E L

\section{Kata Kunci:}

Mandatory Disclosure,

Struktur Kepemilikan,

Kepemilikan Manajerial,

Kepemilikan Publik,

Kepemilikan Asing,

Mekanisme Corporate

Governace, Jumlah Rapat

Dewan Komisaris,

Keberadaan Komisaris

Wanita, Proporsi

Komisaris Independen, dan

Jumlah Anggota Komite

Audit.

Jenis Artikel:

Penelitian Empiris

Correspondence:

Evirahmawati@gmail.com

\author{
A B S T R A K
}

Penelitianini bertujuan untuk menganalisispengaruh struktur kepemilikan danmekanisme corporate governanceterhadaptingkat kepatuhan mandatory disclosurekonvergensi IFRS. Proses identifikasi item tingkat kepatuhan mandatory disclosurekonvergensi IFRS menggunakan item checklistyang dikeluarkan oleh BAPEPAM LK No. VIII.G.7 tahun 2012. Struktur kepemilikan yang digunakan antara lain kepemilikan manajerial, kepemilikan publik, dan kepemilikan asing. Sedangkan mekanisme corporate governanceyang digunakan antara lainjumlah rapat dewan komisaris, keberadaan komisaris wanita, proporsi komisaris independen, dan jumlah anggota komite audit.Sampel penelitianini adalah perusahaan manufakturyang terdaftar pada Bursa Efek Indonesia (BEI) periode 20122015. Alat analisis untuk menguji hipotesis yaitu analisis regresi berganda dan sederhana dengan menggunakan SPSS 23.0.Hasil penelitian ini menunjukkan bahwakepemilikan publik dan keberadaan komisaris wanita berpengaruh positif signifikan terhadap tingkat kepatuhan mandatory disclosurekonvergensiIFRS. Sedangkan kepemilikan manajerial, kepemilikan asing, jumlah rapat dewan komisaris, proporsi komisaris independen, dan jumlah anggota komite audit tidak berpengaruh positif signifikan terhadaptingkat kepatuhan mandatory disclosurekonvergensi IFRS.

(C) 2019 RAB. Published by Universitas Muhammadiyah Yogyakarta

\section{PENDAHULUAN}

Laporan keuangan harus disusun berdasarkan standar akuntansi keuangan yang berlaku. Prosedur, prinsip, dan standar akuntansi yang berbeda oleh setiap negara diakibatkan karena adanya politik, ekonomi, sosial, teknologi, sejarah, budaya, hukum, dan isu-isu lainnya. Adanya perbedaan tersebut maka dibutuhkan Standar Akuntasi Keuangan untuk menyesuaikan dan menyelaraskannya. International Financial Reporting Standard (IFRS) merupakan salah satu standar akuntansi yang diperlukan untuk memudahkan pemahaman laporan keuangan secara internasional. IFRS diterbitkan oleh IASB (International Accounting Standard Board) pada 1 April 2001. Ikatan Akuntan Indonesia (IAI) pada tanggal 23 Desember 2008 mengumumkan rencana Indonesia untuk melakukan konvergensi terhadap IFRS dalam pengaturan standar akuntansi keuangan. Penerapan konvergensi IFRS di Indonesia terbagi menjadi beberapa tahapan. Tahap 
pertama merupakan tahap awal adopsi pada tahun 2008-2011, tahap kedua merupakan tahap persiapan akhir pada tahun 2011, tahap selanjutnya merupakan tahap implementasi pertama pada tahun 2012, dan tahap implementasi kedua yaitu pada tahun 2015.

Perusahaan dapat menyembunyikan informasi penting yang seharusnya diungkapkan, apabila peraturan tentang pengungkapan wajib tersebut tidak ada. Sehingga peraturan tentang pengungkapan wajib pada laporan keuangan perusahaan sangatlah dibutuhkan. Namun masih banyak perusahaan di Indonesia yang belum patuh terhadap pengungkapan wajib. Salah satunya adalah kasus pada tahun 2011, PT Petromine Energy Trading (anak perusahaan PT Bakrie \& Brothers, Tbk) yang tidak mencantumkan pendapatan dari jasa penyediaan bahan bakar kepada AKR Corporindo senilai Rp 1,370 triliun, dengan menggunakan beban pokok pendapatan sebesar Rp 8,000 triliun. Adanya kasus ini, Bakrie \& Brothers mendapatkan sanksi sebesar Rp 4,000 miliar dari Badan Pengawas Pasar Modal dan Lembaga Keuangan (Prayogi, 2011). Kasus seperti PT Bakrie \& Brothers, Tbk ini mengindikasikan pentingnya pengungkapan wajib dalam laporan keuangan perusahaan. Standar akuntansi internasional (IFRS) telah mengatur pengungkapan wajib dalam laporan keuangan. Standar akuntansi yang konvergen dengan IFRS wajib diterapkan oleh semua perusahaan go public dan multinasional di Indonesia untuk menyusun laporan keuangan pada atau setelah 1 Januari 2012 (Gamayuni, 2009).

Utami dkk., (2012) menyatakan bahwa struktur kepemilikan mempengaruhi kepatuhan pengungkapan wajib IFRS. Jika yang membutuhkan informasi tentang perusahaan semakin banyak, maka pengungkapan yang dilakukan oleh perusahaan juga akan semakin detail. Hal ini menjadikan struktur kepemilikan menjadi faktor yang kuat untuk mempengaruhi tingkat kepatuhan pengungkapan.

Mekanisme corporate governance diperlukan untuk mengawasi manajer dan mengelola perusahaan serta untuk menjamin bahwa perusahaan telah mengungkapkan informasi-informasi wajib. Mekanisme corporate governance dapat diproksikan dengan beberapa indikator, beberapa di antaranya adalah jumlah rapat dewan komisaris, keberadaan komisaris wanita, proporsi komisaris independen, dan jumlah anggota komite audit.

Maksud dari penelitian ini adalah untuk menguji kembali mandatory disclosure konvergensi IFRS sebagai variabel dependen serta struktur kepemilikan dan mekanisme corporate governance sebagai variabel independen.

\section{TINJAUAN LITERATUR DAN PERUMUSAN HIPOTESIS}

\section{Teori Agensi (Agency Theory)}

Jensen dan Meckling (1976) mendefinisikan agency theory sebagai hubungan kontrak yang melibatkan satu atau lebih pihak (prinsipal) dan pihak lain (agen) untuk melakukan jasa atas kepentingan mereka termasuk pendelegasian pengambilan keputusan kepada pihak agen. Teori agensi mengungkapkan hubungan antara agen (manajemen) dengan prinsipal (pemegang saham). Agen adalah pihak yang mengelola perusahaan seperti dewan direksi atau manajer selaku pejabat yang berwenang dalam pembuatan keputusan di dalam suatu perusahaan. Sedangkan prinsipal adalah investor atau pemegang saham pada suatu perusahaan.

Agency theory sangat erat hubungannya dengan tingkat kepatuhan mandatory disclosure. Sebagai bentuk transparansi dan akuntabilitas manajemen terhadap investor atau pemegang saham, pihak agents perlu melakukan pengungkapan informasi kepada pihak prinsipal (Sutiyok dan Rahmawati, 2016). 


\section{Pengembangan Hipotesis}

$H_{i} \quad$ : Kepemilikan manajerial berpengaruh positif signifikan terhadap tingkat kepatuhan mandatory disclosure PSAK konvergensi IFRS.

$H_{2}$ : Kepemilikan publik berpengaruh positif signifikan terhadap tingkat kepatuhan mandatory disclosure PSAK konvergensi IFRS.

$H_{3} \quad$ : Kepemilikan asing berpengaruh positif signifikan terhadap tingkat kepatuhan mandatory disclosure PSAK Konvergensi IFRS.

$H_{t}$ :Jumlah rapat dewan komisaris berpengaruh positif signifikan terhadap tingkat kepatuhan mandatory disclosure PSAK konvergensi IFRS.

$H_{s} \quad$ : Keberadaan komisaris wanita berpengaruh positif signifikan terhadap tingkat kepatuhan mandatory disclosure PSAK konvergensi IFRS.

$H_{6} \quad$ : Proporsi Komisaris Independen berpengaruh positif signifikan terhadap tingkat kepatuhan mandatory disclosure PSAK konvergensi IFRS.

$H_{7} \quad$ :Jumlah komite audit berpengaruh positif signifikan terhadap tingkat kepatuhan mandatory disclosure PSAK konvergensi IFRS.

\section{METODE PENELITIAN}

Jenis data yang digunakan peneliti adalah data sekunder yang diperoleh melalui website bursa efek Indonesia. Data sekunder yang digunakan berupa laporan tahunan dari perusahaan manufaktur yang terdaftar di Bursa Efek Indonesia (BEI) tahun 2012-2015. Kriteria yang digunakan dalam memilih sampel adalah sebagai berikut:

1. Perusahaan manufaktur yang terdaftar di Bursa Efek Indonesia (BEI) pada periode 20122015.

2. Perusahaan manufaktur yang mempublikasikan laporan tahunan di Bursa Efek Indonesia (BEI) pada periode 2012-2015.

3. Laporan tahunan yang dipublikasi menyajikan seluruh informasi yang diperlukan dalam pengukuran variabel pada penelitian ini.

Untuk memperoleh informasi, teknik pengumpulan data yang digunakan oleh peneliti yaitu metode arsip (data dokumenter) yang dapat berupa laporan keuangan perusahaan manufaktur, catatan atas laporan keuangan perusahaan manufaktur, dan laporan tahunan perusahaan manufaktur yang terdaftar di Bursa Efek Indonesia (BEI) tahun 2012-2015.

\section{HASIL DAN PEMBAHASAN}

\section{Uji Analisis Statistik Deskriptif}

Hasil penelitian yang dilakukan secara deskriptif dalam penilitian ini dapat dilihat pada Tabel 1. 
Tabel 1 Statistik Deskriptif

\begin{tabular}{llllll}
\hline & $\mathrm{N}$ & Minimum & Maximum & Mean & Std. Deviation \\
\hline KEPMAN & 88 & .00001 & .25603 & .0518983 & .06815981 \\
KEPLIK & 88 & .01985 & .71862 & .2530382 & .16938998 \\
KEPSING & 88 & .01249 & .87315 & .4525695 & .24623667 \\
RADKOM & 88 & 1 & 24 & 5.10 & 3.081 \\
PIKOIN & 88 & .28571 & .50000 & .3812406 & .07219383 \\
JAKODIT & 88 & 3 & 5 & .22 & .513 \\
MANDSCORE & 88 & .55000 & .82000 & .6996591 & .07699006 \\
Valid N (listwise) & 88 & & & & \\
\hline
\end{tabular}

Sumber : Data sekunder yang diolah

\section{Uji Asumsi Klasik Uji Normalitas}

Hasil pengujian normalitas yang dilakukan dengan uji K-S ditunjukkan pada Tabel 2.

Tabel 2 Hasil Uji Normalitas

\begin{tabular}{lll}
\hline \multicolumn{2}{l}{ One-Sample Kolmogorov-Smirnov Test } & \\
\hline & & Unstandardized Residual \\
$\mathrm{N}$ & Mean & 88 \\
Normal Parameters & .0000000 \\
& Std. Deviation & .06963220 \\
Most Extreme Differences & Absolute & .069 \\
& Positive & .061 \\
& Negative & -.069 \\
Test Statistic & & .069 \\
Asymp. Sig. (2-tailed) & & $.200^{\text {c,d }}$ \\
\hline
\end{tabular}

Sumber : Data sekunder yang diolah

Berdasarkan Tabel 2 didapatkan hasil yang menunjukan nilai Asymp. Sig (2- tailed) sebesar $0,200>$ alpha $(0,05)$. Sehingga dapat di asumsikan bahwa data berdistribusi normal.

\section{Uji Multikolinearitas}

Hasil uji multikolinearitas ditunjukkan pada Tabel 3.

Tabel 3 Hasil Uji Multikolinieritas

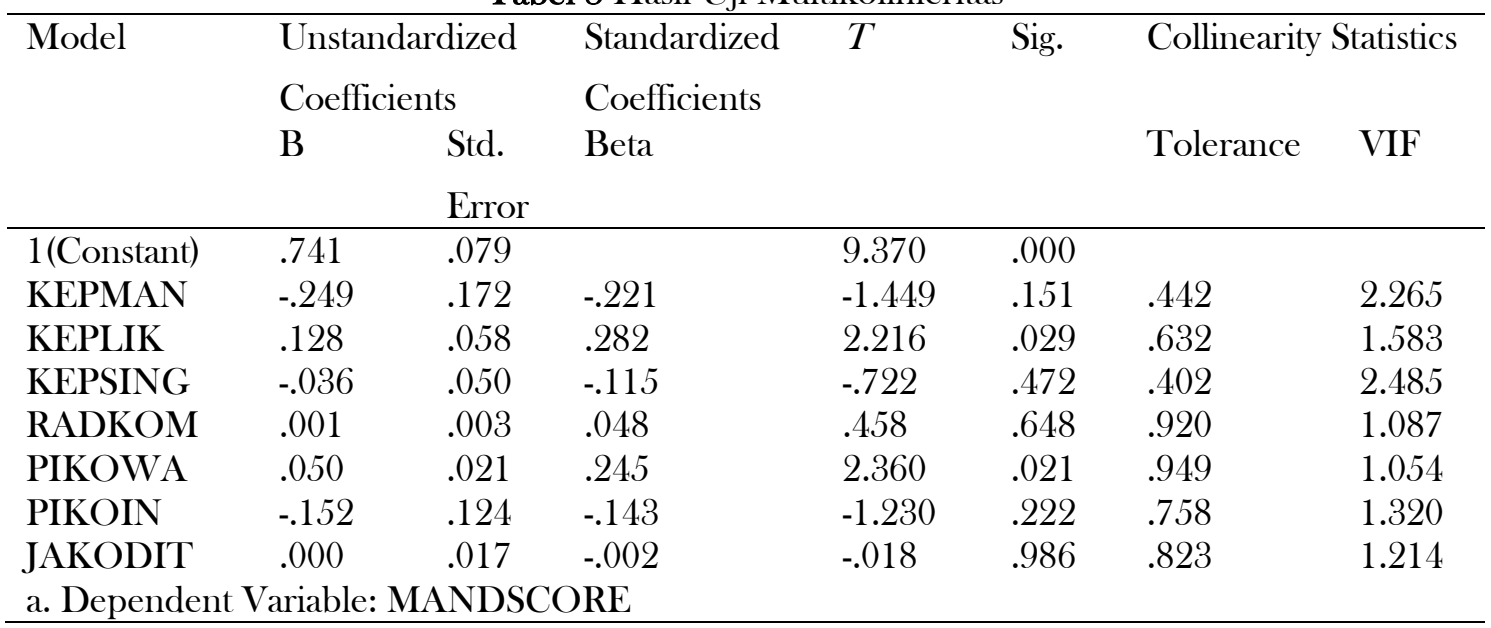

Sumber : Data sekunder yang diolah 
Berdasarkan Tabel 3 didapatkan hasil yang menunjukkan bahwa nilai Variance Inflation Factor (VIF) dari setiap variabel independen berada di bawah 10, sehingga dapat disimpulkan bahwa antar variabel independen tidak terjadi multikolinieritas dan model regresi layak untuk digunakan.

\section{Uji Autokorelasi}

Hasil uji autokorelasi dapat dilihat dengan menggunakan metode Durbin Watson yang ditunjukkan pada Tabel 4 .

Tabel 4 Hasil Uji Autokorelasi

\begin{tabular}{|c|c|c|c|c|c|}
\hline \multirow[b]{2}{*}{ Model } & \multirow[b]{2}{*}{$\mathrm{R}$} & \multirow[b]{2}{*}{ R Square } & \multicolumn{3}{|c|}{ Model Summary } \\
\hline & & & $\begin{array}{l}\text { Adjusted R } \\
\text { Square }\end{array}$ & $\begin{array}{l}\text { Std. Error of the } \\
\text { Estimate }\end{array}$ & Durbin-Watson \\
\hline 1 & $.427^{\mathrm{a}}$ & .182 & .110 & .07261473 & 1.889 \\
\hline \multicolumn{6}{|c|}{$\begin{array}{l}\text { a. Predictors: (Constant), JAKODIT, KEPSING, PIKOWA, RADKOM, PIKOIN, KEPLIK, } \\
\text { KEPMAN } \\
\text { b. Dependent Variable: MANDSCORE }\end{array}$} \\
\hline
\end{tabular}

Sumber : Data sekunder yang diolah

Data yang tidak terjadi Autokorelasi harus memenuhi asumsi dU $<$ DW $<4$ - dU. Hasil uji autokorelasi pada Tabel 4 menunjukkan bahwa nilai Durbin Watson sebesar 1,889 dengan nilai dU sebesar 1,8279 sesuai tabel DW. Berdasarkan hasil uji autokorelasi menunjukkan bahwa 1,8553 $<1,889<4-1,8553$. Sehingga dapat disimpulkan bahwa data tidak terjadi autokorelasi.

\section{Uji Heteroskedastisitas}

Hasil uji heteroskedastisitas menggunakan uji Glejser ditunjukkan pada Tabel 5.

Tabel 5 Hasil Uji Heteroskedastisitas

\begin{tabular}{|c|c|c|c|c|c|c|c|}
\hline \multirow[t]{2}{*}{ Model } & \multicolumn{2}{|c|}{$\begin{array}{l}\text { Unstandardized } \\
\text { Coefficients }\end{array}$} & \multirow{2}{*}{$\begin{array}{l}\text { Standardized } \\
\text { Coefficients } \\
\text { Beta }\end{array}$} & \multirow[t]{2}{*}{$T$} & \multirow[t]{2}{*}{ Sig. } & \multicolumn{2}{|c|}{ Collinearity Statistics } \\
\hline & $\mathrm{B}$ & $\begin{array}{l}\text { Std. } \\
\text { Error }\end{array}$ & & & & Tolerance & VIF \\
\hline 1 (Constant) & .026 & .021 & & 1.201 & .233 & & \\
\hline KEPMAN & -.005 & .046 & -.018 & -.113 & .910 & 442 & 2.265 \\
\hline KEPLIK & -.004 & .016 & -.031 & -.232 & .817 & 632 & 1.583 \\
\hline KEPSING & .022 & .013 & 277 & 1.660 & .101 & 402 & 2.485 \\
\hline RADKOM & .000 & . 001 & .032 & .287 & .775 & .920 & 1.087 \\
\hline PIKOWA & .000 & .006 & .009 & 079 & .937 & .949 & 1.054 \\
\hline PIKOIN & -.056 & .033 & -.204 & -1.676 & .098 & .758 & 1.320 \\
\hline JAKODIT & .005 & .005 & .120 & 1.026 & 308 & .823 & 1.214 \\
\hline a. Depender & Varia & $\mathrm{ABS}_{-}$ & & & & & \\
\hline
\end{tabular}

Sumber : Data sekunder yang diolah

Berdasarkan Tabel 5 didapatkan hasil yang menunjukkan bahwa nilai signifikansi setiap variabel independen memiliki nilai signifikansi > alpha $(0,05)$. Sehingga dapat disimpulkan bahwa data tidak terjadi heteroskedastisitas.

\section{Hasil Penelitian (Uji Hipotesis)}

Uji Koefisien Determinasi $\left(R^{\prime}\right)$ 
Berdasarkan pengujian pada Tabel 8 dapat diketahui persamaan regresi linier berganda adalah sebagai berikut:

\section{MANDSCORE $=0,741-0,249($ KEPMAN) $\quad+$ 0,128(KEPLIK) $\quad-\quad 0,036($ KEPSING) $\quad+$ 0,001 (RADKOM) + 0,050(PIKOWA) - 0,152(PIKOIN) + 0,000(JAKODIT) + e}

Dari hasil persamaan regresi linier berganda menggunakan uji $t$ statistik, dapat diketahui hasil pengujian terhadap hipotesis-hipotesis penelitian adalah sebagai berikut:

a Kepemilikan Manajerial terhadap Tingkat Kepatuhan Mandatory Disclosure Konvergensi IFRS

Berdasarkan Tabel 8 nilai sig. untuk variabel kepemilikan manajerial (KEPMAN) sebesar 0,151 $>$ alpha $(0,05)$ dengan nilai koefisien regresi sebesar - 0,249. Hal tersebut menunjukkan bahwa kepemilikan manajerial (KEPMAN) tidak berpengaruh positif signifikan terhadap tingkat kepatuhan mandatory disclosure (MANDSCORE). Sehingga hipotesis pertama $\left(\mathrm{H}_{1}\right)$ ditolak.

\section{b. Kepemilikan publik terhadap Tingkat Kepatuhan Mandatory Disclosure Konvergensi IFRS}

Berdasarkan Tabel 8, nilai sig. untuk variabel kepemilikan public (KEPLIK) sebesar 0,029 < alpha $(0,05)$ dengan nilai koefisien regresi sebesar 0,128 . Hal tersebut menunjukkan bahwa variabel kepemilikan publik (KEPLIK) berpengaruh positif signifikan terhadap tingkat kepatuhan mandatory disclosure (MANDSCORE). Sehingga hipotesis kedua $\left(\mathrm{H}_{2}\right)$ diterima.

c. Kepemilikan Asing terhadap Tingkat Kepatuhan Mandatory Disclosure Konvergensi IFRS

Berdasarkan Tabel 8 nilai sig. untuk variabel kepemilikan asing (KEPSING) sebesar 0,472 > alpha $(0,05)$ dengan nilai koefisien regresi sebesar $-0,036$. Hal tersebut menunjukkan bahwa kepemilikan asing (KEPSING) tidak berpengaruh positif signifikan terhadap tingkat kepatuhan mandatory disclosure (MANDSCORE). Sehingga hipotesis ketiga $\left(\mathrm{H}_{3}\right)$ ditolak.

d. Jumlah Rapat Dewan Komisaris terhadap Tingkat Kepatuhan Mandatory Disclosure Konvergensi IFRS

Berdasarkan Tabel 8 nilai sig. untuk variabel rapat dewan komisaris (RADKOM) sebesar 0,648 $>$ alpha $(0,05)$ dengan nilai koefisien regresi sebesar 0.01 . Hal tersebut menunjukkan bahwa jumlah rapat dewan komisaris (RADKOM) tidak berpengaruh positif signifikan terhadap tingkat kepatuhan mandatory disclosure (MANDSCORE). Sehingga hipotesis keempat $\left(\mathrm{H}_{4}\right)$ ditolak.

e. Keberadaan Komisaris Wanita terhadap Tingkat Kepatuhan Mandatory Disclosure Konvergensi IFRS

Berdasarkan Tabel 8, nilai sig. untuk variabel keberadaan komisaris wanita (PIKOWA) sebesar $0,021<$ alpha $(0,05)$ dengan nilai koefisien regresi sebesar 0,050 . Hal tersebut menunjukkan bahwa variabel keberadaan komisaris wanita (PIKOWA) berpengaruh positif signifikan terhadap tingkat kepatuhan mandatory disclosure (MANDSCORE). Sehingga hipotesis kelima $\left(\mathrm{H}_{5}\right)$ diterima.

f Proporsi Komisaris Independen terhadap Tingkat Kepatuhan Mandatory Disclosure Konvergensi IFRS

Berdasarkan Tabel 8 nilai sig. untuk variabel proporsi komisaris independen (PIKOIN) sebesar $0,222>$ alpha $(0,05)$ dengan nilai koefisien regresi sebesar - 0,152. Hal tersebut menunjukkan bahwa proporsi komisaris independen (PIKOIN) tidak berpengaruh positif signifikan terhadap 
tingkat kepatuhan mandatory disclosure (MANDSCORE). Sehingga hipotesis keenam $\left(\mathrm{H}_{6}\right)$ ditolak.

\section{g Jumlah Anggota Komite Audit terhadap Tingkat Kepatuhan Mandatory Disclosure Konvergensi IFRS}

Berdasarkan Tabel 8 nilai sig. untuk variabel jumlah anggota komite audit (JAKODIT) sebesar $0,986>$ alpha $(0,05)$ dengan nilai koefisien regresi sebesar 0,000 . Hal tersebut menunjukkan bahwa jumlah anggota komite audit (JAKODIT) tidak berpengaruh positif signifikan terhadap tingkat kepatuhan mandatory disclosure (MANDSCORE). Sehingga hipotesis ketujuh $\left(\mathrm{H}_{7}\right)$ ditolak.

\section{KETERBATASAN PENELITIAN}

Keterbatasan pada penelitian ini adalah sampel yang digunakan dalam penelitian ini hanya terfokus pada perusahaan manufaktur yang terdaftar di Bursa Efek Indonesia (BEI), sehingga kesimpulan yang dihasilkan dari penelitian ini tidak dapat digeneralisasi untuk jenis perusahaan lain. Periode pengamatan dalam penelitian ini relatif pendek yaitu 4 tahun dari tahun 2012 - 2015, sehingga sangat besar kemungkinan sampel tidak mampu merepresentasikan populasi dengan baik. Variabel independen yang digunakan dalam penelitian ini hanya menjelaskan $11 \%$ dari variabel dependen, sisanya dijelaskan oleh variabel lain yang tidak dimasukkan dalam model penelitian.

\section{KESIMPULAN}

\section{Simpulan}

Berdasarkan analisis dan pengujian data dalam penelitian ini, dapat ditarik kesimpulan kepemilikan manajerial tidak berpengaruh positif signifikan terhadap tingkat kepatuhan mandatory disclosure konvergensi IFRS. Kepemilikan publik berpengaruh positif signifikan terhadap tingkat kepatuhan mandatory disclosure konvergensi IFRS. Kepemilikan asing tidak berpengaruh positif signifikan terhadap tingkat kepatuhan mandatory disclosure konvergensi IFRS. Jumlah rapat dewan komisaris tidak berpengaruh positif signifikan terhadap tingkat kepatuhan mandatory disclosure konvergensi IFRS. Keberadaan komisaris wanita berpengaruh positif signifikan terhadap tingkat kepatuhan mandatory disclosure konvergensi IFRS. Proporsi komisaris independen tidak berpengaruh positif signifikan terhadap tingkat kepatuhan mandatory disclosure konvergensi IFRS. Jumlah anggota komite audit tidak berpengaruh positif signifikan terhadap tingkat kepatuhan mandatory disclosure konvergensi IFRS.

\section{Saran}

Berdasarkan hasil penelitian yang telah diperoleh, maka dapat diberikan saran sebagai berikut:

1. Penelitian selanjutnya disarankan untuk menambah variabel penelitian yang lebih luas yang dapat mempengaruhi tingkat kepatuhan mandatory disclosure konvergensi IFRS.

2. Penelitian selanjutnya disarankan dapat memperluas item pengungkapan karena penelitian ini hanya berfokus pada item pengungkapan wajib pada laporan laba rugi saja.

3. Penelitian selanjutnya disarankan untuk memperpanjang periode penelitian agar sampel mampu merepresentasikan populasi dengan lebih baik. 
4. Penelitian selanjutnya disarankan untuk menggunakan sampel seluruh perusahaan yang terdaftar di Bursa Efek Indonesi (BEI) agar hasil penelitian mendukung kesimpulan yang lebih akurat.

\section{DAFTAR PUSTAKA}

Alvionita, I., \& Taqwa, S. (2015). Pengaruh Struktur Kepemilikan dan Mekanisme Corporate Governance Terhadap Tingkat Kepatuhan Mandatory Disclosure. Seminar Nasional Ekonomi Manajemen dan Akuntnasi (SNEMA) Fakuktas Ekonomi, Universitas Negeri Padang.

Badan Pengawas Pasar Modal Dan Lembaga Keuangan. (2010). Analisis Pelaksanaan dan Tata Kelola Emiten dan Perusahaan Publik.

Barros, C. P., Boubaker, S., \& Hamrouni, A. (2013). Corporate Governance and Voluntary Disclosure in France. Journal of Applied Business Research (JABR), 29 (2), 561-578.

Diyanti, F. (2010). Mekanisme Good Corporate Governance, Karakteristik Perusahaan dan Mandatory Disclosure: Studi Empiris pada Perusahaan Manufaktur yang Terdaftar di BEI. Publikasi Ilmiah Program Magister Sains Akuntansi Fakultas Ekonomi Unversitas Brawijaya.

Gamayuni, R. R. (2009). Perkembangan Standar Akuntansi Keuangan Indonesia Menuju International Financial Reporting Standards. Jurnal Akuntansi dan Keuangan 14 (2), 153166.

Ghozali, I. (2011). Aplikasi Analisis Multivariate Dengan Program IBM SPSS 19 (edisi kelima).Semarang: Universitas Diponegoro.

Gunawan, B., \& Hendrawati, E. H. (2016). Peran Struktur Corporate Governance dalam Tingkat Kepatuhan Pengungkapan Wajib Periode Setelah Konvergensi IFRS (Studi pada Perusahaan Manufaktur yang Terdaftar di Bursa Efek Indonesia). Berkala Akuntansi dan Keuangan Indonesia, 1 (2016): $71-8$

Hafiz, R., Adriani, A., Chairina. (2015). Pengaruh Struktur Corporate Governance Terhadap Tingkat Kepatuhan Pengungkapan Wajib Konvergensi IFRS Pada Laporan Laba Rugi Komprehensif. Simposium Nasional Akuntansi Xviil, Medan.

Hardiningsih, P. (2008). Analisis Faktor-faktor Yang Mempengaruhi Voluntary Disclosure Laporan Tahunan Perusahaan. Jurnal Bisnis dan Ekonomi (JBE), 15, (1).

Jensen, M. C., \& Meckling, W. H. (1976). Theory of the firm: Managerial behavior, agency costs and ownership structure. Journal of financial economics, 3(4), 305-360.

Juniarti. (2009). Pengaruh Good Corporate Governance, Voluntary Disclosure Terhadap Biaya Hutang (Costs Of Debt). Jurnal Akuntansi dan Keuangan, 11, (2), 88-100.

Kharis, A., \& Suhardjanto, D. (2012). Corporate Governance Dan Ketaatan Pengungkapan Wajib Pada Badan Usaha Milik Negara. Jurnal Keuangan Dan Perbankan, 16 (1).

Komite Nasional Kebijakan Governance. (2006). Pedoman Umum Good Corporate Governance Indonesia.

Kusumastuti, S., Supatmi, \& Sastra, P. (2007). Pengaruh Board Diversity terhadap Nilai Perusahaan dalam Prespektif Corporate Governance. Jurnal Akuntansi dan Keuangan, 9(2), 88-98.

Listyani, T. T. (2003). Kepemilikan Manajerial Dan Pengaruhnya Terhadap Kepemilikan Saham Institusional. Jurnal Politeknik Negeri Semarang Vol 3.

Nasution, M., \& D. Setiawan. (2007). Pengaruh Corporate Governance Terhadap Manajemen Laba di Industri Perbankan Indonesia. Simposium Nasional Akuntansi X Makassar: 126.

Nazaruddin, I, \& Basuki, A. T., (2015). Analisis Statistik dengan SPSS

Nugroho, P. I., \& Poluan, G. (2015). Pengaruh Mekanisme Corporate Governance Dan Kondisi Financial Distress Terhadap Luas Pengungkapan Sukarela Dalam Laporan Tahunan Perusahaan”. Jurnal Dinamika Akuntansi, keuangan dan Perbankan, 4 (1), 39-56.

Nur, M., \& Priantinah, D., (2012). Analisis Faktor-Faktor Yang Mempengaruhi Pengungkapan Corporate Social Responsibility Di Indonesia (Studi Empiris Pada Perusahaan Berkategori High Profile yang Listing Di Bursa Efek Indonesia), Jurnal Nominal, 1(1). 
Nurkhin, A. (2009). Corporate Governance dan Profitabilitas; Pengaruhnya Terhadap Pengungkapan Tanggung Jawab Sosial Perusahaan (Studi Empiris Pada Perusahaan yang Tercatat di Bursa Efek Indonesia). Dalam Jurnal Magister Akuntansi, 2 (1).

Pamungkas, H S., \& Puspaningsih, A. (2013). Pengaruh Keputusan Investasi, Keputusan Pendanaan, Kebijakan Dividend an Ukuran Perusahaan Terhadap Nilai Perusahaan. JAAI $17(2)$.

Paramita, A. D., \& Marsono. (2014). Pengaruh Karakteristik Corporate Governance Terhadap Luas Pengungkapan Corporate Social Responsibility. DiponegoroJournal Of Accounting, 3 (1).

Pitasari, A., \& Septiani, A. (2014). Analisis Pengaruh Struktur Corporate Governance Terhadap Tingkat Kepatuhan Pengungkapan Konvergensi IFRS Pada Laporan Laba Rugi Komprehensif. (Doctoral Dissertation, Fakultas Ekonomika Dan Bisnis).

Pratista, D. F. (2016). Pengaruh Kepemilikan Manajerial, Political Visibility, Kinerja Keuangan, dan Board Gender terhadap Environmental Disclosure. Repository, UMY.

Prawinandi, W., Suhardjanto, D., \& Triatmoko, H. (2012). Peran Struktur Corporate Governance Dalam Tingkat Kepatuhan Mandatory Disclosure Konvergensi IFRS”. Simposium Nasional Akuntansi $X_{V}$, Banjarmasin.

Prayogi, W. E. (2011). Bapepam Telusuri Salah Catat Laporan Keuangan Bakrie \& Brothers. http://finance.detik.com/read/2011/05/02/183124/1630743/6/bapepam-telusuri-salahcatatlaporan-keuangan-bakriebrothers. 31 Desember 2016.

Putra, I. (2013). Pengaruh Tingkat Pengungkapan Item Corporate Social Responsibility Terhadap Manajemen Laba (Studi Pada Perusahaan Yang Terdaftar Di Indeks Sri-Kehati Selamatahun 2009-2011), Doctoral dissertation, UAJY.

Putranto, R. J., \& Raharja, S. (2013). Faktor-Faktor Yang Mempengaruhi Luas Pengungkapan Corporate Governance Dalam Laporan Tahunan Perusahaan Perbankan Yang Terdaftar Di Bursa Efek Indonesia Tahun 2008-2011. Doctoral Dissertation, Fakultas Ekonomika Dan Bisnis.

Putri, G. D. K. (2011). Pengaruh Struktur Kepemilikan, Ukuran Perusahaan, dan Umur Perusahaan Terhadap Kinerja Intellectual Capital. Skripsi. Semarang: Universitas Diponegoro.

Rahindayati. (2015). Pengaruh Diversitas Pengurus Pada Luas Pengungkapan Corporate Social Responsibility Perusahaan Sektor Keuangan Yang Terdaftar Di Bursa Efek Indonesia. Skripsi Program Pascasarjana Universitas Udayana Denpasar.

Rita, M. R., \& Sartika. (2013). Pengaruh Profitabilitas dan Kepemilikan Saham Publik Terhadap Luas Pengungkapan Corporate Social Responsibility (CSR). Jurnal Universitas Kristen Satya Wacana.

Sari, D. P., \& Andayani. (2015). Pengaruh Kinerja Keuangan Dan Struktur Kepemilikan Terhadap Pengungkapan Laporan Keuangan Perusahaan Jasa. Jurnal Ilmu \& Riset Akuntansi, Vol. 4 No.10.

Sari, R. Y. H. K. (2012). Ownership Retention, Komisaris Independen, Proprietary Cost dan Pengungkapan Intellectual Capital Dalam Prospektus IPO. Jurnal Akuntansi dan Sistem Teknologi Informasi, 9(1), 76-90.

Supriyono, E., Mustaqim, A. A., Suhardjanto, D. (2014). Pengaruh Corporate Governance Terhadap Tingkat Kepatuhan Mandatory Disclosure Konvergensi IFRS Di Indonesia. Simposium Nasional Akuntansi Xvii, Mataram.

Sutiyok, S., \& Rahmawati, E. (2016). Pengaruh Mekanisme Corporate Governance Terhadap Tingkat Kepatuhan Mandatory Disclosure Konvergensi IFRS di Perbankan. Jurnal Akuntansi Dan Investasi, 15(2), 151-162.

Taman, A., Istiningrum, A. A., \& Nugroho M. A. (2014). Pengaruh Karakteristik Perusahaan Terhadap Luas Pengungkapan Wajib Pada PSAK Adopsi IFRS Dan Dampaknya Terhadap Stock Return. Skripsi Fakultas Ekonomi Universitas Negeri Yogyakarta. 
Tamba, E. G. H. (2011). Pengaruh Struktur Kepemilikan Terhadap Pengungkapan Tanggung Jawab Sosial Perusahaan (Studi Empiris pada Perusahaan Manufacturing Secondary Sectors yang Listing di BEI tahun 2009). Skripsi Fakultas Ekonomi. Universitas Diponegoro.

Tondombala, S. A. A., \& Lastanti, H. S. (2016). Peran Struktur Corporate Governance Dalam Tingkat Kepatuhan Mandatory Disclosure IFRS. Jurnal FEB, Universitas Trisakti, 3 (1).

Utami, W. D., D. Suhardjanto, \& S. Hartoko. (2012). Investigasi dalam Konvergensi IFRS Di Indonesia: Tingkat Kepatuhan Pengungkapan Wajib dan Kaitannya dengan Mekanisme Corporate Governance. Proceeding Simposium Nasional Akuntansi XV. Banjarmasin.

Waryanto, W., Handayani, S., \& Handayani, S. (2010). Pengaruh Karakteristik Good Corporate Governance (GCG) Terhadap Luas Pengungkapan Corporate Social Responsibility (CSR) Di Indonesia. (Doctoral Dissertation, Perpustakaan FE Undip).

Widjayanti, S. A., \& Wahidawati. (2015). Pengaruh Struktur Dan Mekanisme Corporate Governance Pada Tingkat Kepatuhan Mandatory Disclosure Konvergensi IFRS. Jurnal Ilmu \& Riset Akuntansi, 4 (7).

Yulia, A., \& Ermawati. (2012). Pengaruh Solvabilitas, Status Perusahaan, dan Kepemilikan Publik terhadap Luas Pengungkapan Wajib (Mandatory Disclosure) Laporan Tahunan pada Perusahaan Perbankan yang Terdaftar di Bursa Efek Indonesia. Jurnal Perspektif Manajemen dan Perbankan.

Yuliana, R. D. (2016). Pengaruh IFRS Convergence, Corporate Governance, dan Ownership Structure terhadap Tingkat Kepatuhan Mandatory Disclosre. Repository, UMY.

Yuliawati, R., \& Sukirman. (2015). Faktor-faktor Yang Mempengaruhi Pengungkapan Corporate Social Responsibility. Accounting Analysis Journal 4. 